\title{
Identifying the Principal Factors Affecting the Selection of Higher Education Economical Studies in Greece
}

\author{
Odysseas Moschidis \\ Department of Marketing and Operations Management, University of Macedonia \\ 49 Ag. Dimitriou Str., Edessa, 58200, Greece \\ E-mail: fmos@uom.gr
}

Vassilis Kostoglou (Corresponding author)

Department of Informatics, Alexander Technological Educational Institute of Thessaloniki

P.O. Box 141, Thessaloniki, 57400, Greece

E-mail: vkostogl@it.teithe.gr

\begin{abstract}
Jason Papathanasiou
Department of Marketing and Operations Management, University of Macedonia

49 Ag. Dimitriou Str., Edessa, 58200, Greece

E-mail: jasonp@uom.gr
\end{abstract}

Received: December 26, 2012

Accepted: January 27, 2013 Published: April 1, 2013

doi:10.5296/jmr.v5i2.2957

URL: http://dx.doi.org/10.5296/jmr.v5i2.2957

\begin{abstract}
This paper presents a study of the factors affecting the selections of university departments for undergraduate studies made by high school graduates in Greece; crucial decisions affecting both the vocational career of the individuals as well as the labor market at national level. It is therefore important for the economic development of a country to understand how people come early to decisions that have a significant effect in their career. The factors under consideration have been identified by the high school candidates for university introductory exams in Greece. A methodology is introduced based on correspondence analysis for estimating the importance of the factors affecting a certain outcome and a structured questionnaire has been designed for this purpose, covering several socioeconomic factors
\end{abstract}




\section{Macrothink}

Journal of Management Research

ISSN 1941-899X

2013, Vol. 5, No. 2

which were considered as important by the students in their decision making procedure. The methodology is then used to estimate the impact of 18 factors influencing the order of preference of 318 male and 454 female high school students in their final selection of economical university departments. The paper also reveals whether there is any differentiation or harmonization among groups of students, such as between the two genders, with respect to these factors.

Keywords: Higher education, Economical studies, Economic development, Correspondence analysis, Comparative evaluation 


\section{Introduction}

Selecting a department for undergraduate studies is a significant decision that has a substantial and long lasting impact on both the personal career of an individual and the labor market of a country. It is also important from the point of view of policy making of the ministries of education and labor, as well as of the economic growth of a country, to understand how people make early choices that have a major impact on their careers. To this purpose a structured questionnaire was developed that has been completed by 772 university students. The questions covered various factors, mainly socio-economic ones, which have been considered to play an important role for the decision of the students. The questionnaire was based on more than 20 years of experience of one of the authors with high school candidates to introductory exams for Greek universities. The methodology used is based on correspondence analysis (Lebart et al 2002), in order to analyze the collected information of the respondents.

Two pieces of the applied methodology are presented briefly aiming to study the issue at hand: a) the questions designed for the study are presented; and b) a methodology is discussed for estimating the impact of factors influencing the selection of university departments made by the students and for finding out if there is any differentiation or harmonization in the factors' importance across groups of subjects, such as across gender.

\section{Literature Review}

Several prior studies employing a variety of different factors, have examined the criteria used by students in accounting discipline when selecting their career. Other studies have examined the impact of factors influencing the selection of university departments made by business students in respect with their past choices of undergraduate studies as high school candidates for university introductory exams.

In the accounting literature, several career-choice studies have been conducted to identify factors influencing individuals in choosing accounting as a career (Ashworth, 1969; Carpenter and Strawser, 1970; Evans, 1974; Thielens, 1974; Triandis et al., 1988; Gul et al., 1989; Horowitz and Riley, 1990; Triandis et al., 1990; Markus and Kitayama, 1991; Bundy and Norris, 1992; Felton et al., 1994; Auyeung and Sands, 1997; Lowe and Simons, 1997; Saemann and Crooker, 1999).

Firstly, Ginzberg (1951) identified three categories of occupational-choice dimensions and groups these as values: concomitant value, extrinsic value and intrinsic value. O' Connor and Kinnane (1961) used six factors for the analysis of preference questionnaires: independence-variety, work conditions and associates, social-artistic, security and material aspects, prestige, and heuristics and creativity. Paolillo and Estes (1982) reported that the majority of engineers and physicians decided on their career path prior to leaving high school, while the majority of attorneys decided after having attended two years in a college. According to their findings, most of the accounting professionals also made their decision in the second year of college or before.

Cohen and Hanno (1993) examined business students' selection of majors in the US and 
reported differences in rationales and intentions between accounting and non-accounting business majors. Kamran et al. (1997) examined in their study the influence of intrinsic factors, financial and job-related factors plus other factors such as parent and peer influence and work experience. They also examined the students' perceived benefit-cost ratio to being a chartered accountant and whether accounting students choose to pursue a chartered accountancy career or a non-accounting career.

Dynan and Rouse (1997), Lewis and Norris (1997) and Jensen and Owen (2000) have identified the importance of interest and perceptions of the profession as factors determining the selection of an economic major. Albrecht and Sack (2001) have also commented on finance as an attractive alternative to accounting. Gammie et al. (2003) examined gender differences across several performance measures both prior to and after entering into accounting and finance higher education studies. No gender differences were found in any of the final year modules, and this was also evident in the coursework and examination performance analysis. Worthington and Higgs (2003) examined in their study the role of student characteristics, personality and perceptions of the banking and finance professions in determining the selection of an undergraduate finance major. Among the examined student characteristics were gender, secondary school studies in accounting, business and economics, degree grade average and frequency of attendance.

The motivation behind the present study is a conviction in the need for both understanding and estimating the impact of the factors, mainly the socioeconomic ones, which influence the decision selections of potential accounting and finance students.

\section{Factors for Selecting University Departments}

The factors (criteria) that were considered to be central for the choices of university departments made by high school students were based solely on the ad hoc experience of one of the authors who has been preparing students for university entry exams for over 20 years. To the best of the authors' knowledge this is the first study of this kind where both the factors/questionnaires and the subjects asked are solely based on the experience and relation of a teacher with his/her students over the years. Hopefully other studies on this important topic can benefit from this experience and the applied methodology and results.

As the factors are based on implicit knowledge - and not, for example, on other past studies on this topic - they are presented without further analysis based on existing literature. Although this entails the danger of either "reinventing the wheel" or of making empirical study errors, it is believed that there is value in simply presenting the implicit knowledge on the subject matter gained from years of experience from which other researchers can also potentially benefit as well. The factors, with their code name used preceding them, are presented in Table 1. The students were asked the following question: "On a scale from 1 to 5, to what extent has each of the following factors influenced your choice of university department?" Among the 772 students questioned, there were 318 boys and 454 girls. 
Table 1. Examined factors and corresponding code names

\begin{tabular}{ll}
\hline Code name & Factor \\
\hline E11_1 & Family influence \\
E11_2 & School/teachers influence \\
E11_3 & Social environment influence regarding the general area of studies \\
E11_4 & Mass media \\
E11_5 & Employment prospects, as perceived \\
E11_6 & Interest/like in subject of studies \\
E11_7 & Father's profession \\
E11_8 & Mother's profession \\
E11_9 & Distance between university and family's residence \\
E11_10 & City where the department is situated \\
E11_11 & High-school friends' influence \\
E11_12 & Family's financial status \\
E11_13 & Entertainment in student life, as perceived and expected \\
E11_14 & Independence from parents, as expected \\
E11_15 & Special talents \\
E11_16 & Studies that are considered/perceived as important today and in the future \\
E11_17 & Social recognition of the university department degree \\
E11_18 & $\begin{array}{l}\text { Psychological repercussions on the family due to the great distance between university and } \\
\text { family residence }\end{array}$ \\
\hline
\end{tabular}

\section{Estimating the Importance of Factors}

The main focus was on a comparative evaluation of the factors that influence two or more "subject groups", such as the choice of male and female high school students. To this purpose a methodology was developed for finding and estimating the importance of factors for a certain outcome - in this case how the 18 factors shown above influence the university department choices. The methodology consists of the following steps, which are described as they are performed for the particular case of comparing male and female students (but can be clearly generalized in a straight forward way for comparisons across other subject groups):

1. Firstly two tables were created with the answers of the subjects to the 18 factors/ questions (on the $1-5$ scale): one is a $318 \times 18$ table for the 318 male students, while the other is a table $454 \times 18$ for the 454 female students. 


\section{Macrothink}

2. As the correspondence analysis was performed in the last step it was required that all factors/questions are measured on the same scale. If the factors were initially evaluated on different scales, they must be transformed into scales of equal number of ranks. This was achieved out with the use of the DIAS software (Moschidis, 2003). In this specific case all answers to the 18 factors/questions above were reduced to a 3-point evaluation scale ("no", "quite", "very" regarding the importance of each of the 18 factors). With the new scale each point $(1,2,3,4,5)$ of the 5-point scale was transformed into a percentage triad (Moschidis, 2003). In particular, point 1 is transformed in the percentage triad $(90,7,3)$ meaning that there is a probability of $90 \%$ for $1,7 \%$ for 2 , and $3 \%$ for 3 . Table 2 presents the percentage triads finally used for each point of the 1-5 initial scale.

Table 2. Percentage table in triads

\begin{tabular}{ccccc}
\hline Points on a 5-point scale & \multicolumn{2}{c}{ Percentage on a triad scale } & Total \\
\hline 1 & 90 & 7 & 3 & 100 \\
2 & 70 & 20 & 10 & 100 \\
3 & 17 & 67 & 17 & 100 \\
4 & 10 & 20 & 70 & 100 \\
5 & 3 & 7 & 90 & 100 \\
\hline
\end{tabular}

Based on this scale transformation, Table 2 can be transformed into Tables 3 (male students) and 4 (female students) by simply having one row per factor and each factor measured in a 3-point "percentage" scale (Moschidis, O. 2006). 
Table 3. Male students' evaluation table

\begin{tabular}{lccc}
\hline Factor & A1 & A2 & A3 \\
\hline E11_1 & 15585 & 8330 & 7715 \\
E11_2 & 20299 & 6820 & 4465 \\
E11_3 & 14553 & 8729 & 8360 \\
E11_4 & 19177 & 6495 & 5912 \\
E11_5 & 3808 & 5831 & 21909 \\
E11_6 & 4883 & 6240 & 20433 \\
E11_7 & 22016 & 4759 & 4765 \\
E11_8 & 25638 & 3620 & 2254 \\
E11_9 & 19317 & 5838 & 6411 \\
E11_10 & 11520 & 7062 & 13004 \\
E11_11 & 22108 & 5815 & 3647 \\
E11_12 & 19370 & 6555 & 5661 \\
E11_13 & 13358 & 8257 & 10013 \\
E11_14 & 17855 & 6455 & 7264 \\
E11_15 & 12383 & 7611 & 11622 \\
E11_16 & 5472 & 6634 & 19464 \\
E11_17 & 9441 & 8604 & 13595 \\
E11_18 & 23425 & 4981 & 3144 \\
\hline
\end{tabular}

The meaning of the numbers in the cells is as follows: number 6495 on the $4^{\text {th }}$ row and the second column gives the number of the total points that the boys gave to the characterization "quite" in the question: "to what extent have the mass media influenced your choice of department?" (E11_4), since code A1 on the first line means that the reference is to male students (A) answering "no" (1), code A2 shows male students answering "quite" (2) and code A3 male students answering "very" (3). A similar table has been formed for the female students (Table 4). 
Table 4. Female students' evaluation table

\begin{tabular}{lccc}
\hline Factor & K1 & K2 & K3 \\
\hline E11_1 & 19316 & 12472 & 13382 \\
E11_2 & 25902 & 11435 & 7811 \\
E11_3 & 19287 & 12176 & 13685 \\
E11_4 & 26845 & 9787 & 8468 \\
E11_5 & 4120 & 7289 & 33593 \\
E11_6 & 6153 & 10368 & 28565 \\
E11_7 & 32431 & 5990 & 6591 \\
E11_8 & 35407 & 5461 & 4132 \\
E11_9 & 27057 & 8231 & 9774 \\
E11_10 & 14345 & 10383 & 20378 \\
E11_11 & 32191 & 7647 & 5208 \\
E11_12 & 26688 & 9597 & 8813 \\
E11_13 & 18718 & 12065 & 14373 \\
E11_14 & 24330 & 9544 & 11214 \\
E11_15 & 20288 & 11789 & 13075 \\
E11_16 & 6952 & 10123 & 28005 \\
E11_17 & 11049 & 12511 & 21610 \\
E11_18 & 32087 & 8010 & 4965 \\
\hline
\end{tabular}

$\mathrm{K}$ shows that we refer to females and the indices 1, 2, and 3 point to the answers "no", "quite", and "very" respectively

3. Then a single table is created by merging the two tables for the two subject groups (males and females in this case) created above. This leads to Table 5. 


\section{Macrothink}

Table 5. Final table of comparative evaluation (male - female)

\begin{tabular}{ccccccc}
\hline Factor & A1 & A2 & A3 & K1 & K2 & K3 \\
\hline E11_1 & 15585 & 8330 & 7715 & 19316 & 12472 & 13382 \\
E11_2 & 20299 & 6820 & 4465 & 25902 & 11435 & 7811 \\
E11_3 & 14553 & 8729 & 8360 & 19287 & 12176 & 13685 \\
E11_4 & 19177 & 6495 & 5912 & 26845 & 9787 & 8468 \\
E11_5 & 3808 & 5831 & 21909 & 4120 & 7289 & 33593 \\
E11_6 & 4883 & 6240 & 20433 & 6153 & 10368 & 28565 \\
E11_7 & 22016 & 4759 & 4765 & 32431 & 5990 & 6591 \\
E11_8 & 25638 & 3620 & 2254 & 35407 & 5461 & 4132 \\
E11_9 & 19317 & 5838 & 6411 & 27057 & 8231 & 9774 \\
E11_10 & 11520 & 7062 & 13004 & 14345 & 10383 & 20378 \\
E11_11 & 22108 & 5815 & 3647 & 32191 & 7647 & 5208 \\
E11_12 & 19370 & 6555 & 5661 & 26688 & 9597 & 8813 \\
E11_13 & 13358 & 8257 & 10013 & 18718 & 12065 & 14373 \\
E11_14 & 17855 & 6455 & 7264 & 24330 & 9544 & 11214 \\
E11_15 & 12383 & 7611 & 11622 & 20288 & 11789 & 13075 \\
E11_16 & 5472 & 6634 & 19464 & 6952 & 10123 & 28005 \\
E11_17 & 9441 & 8604 & 13595 & 11049 & 12511 & 21610 \\
E11_18 & 23425 & 4981 & 3144 & 32087 & 8010 & 4965 \\
\hline
\end{tabular}

4. The final table created (table 5, Zardas, G., Moschidis,2011) has been analyzed using standard correspondence analysis (Lebart et al., 2002).

\section{Results}

The analysis of Table 3 leads to the following histogram of characteristic roots (Table 6).

Table 6. Characteristic roots histogram

\begin{tabular}{cccc}
\hline Factorial axis & \% of variance explained & $\begin{array}{c}\text { Total \% of variance } \\
\text { explained }\end{array}$ & \\
1 & 94.59 & 94.59 & \\
2 & 4.80 & 99.38 & \\
3 & 0.48 & 99.86 & \\
4 & 0.14 & & 100 \\
\hline
\end{tabular}

The interpretation percentage $(94.59 \%)$ of the first factorial axis is very large. This means that the first factorial axis actually interprets almost the entirety of the phenomenon and is supplemented by the second axis which interprets another $4.8 \%$. The indicators of interpretation CTR (contribution) and COR (correlation) produced: 
(1) The contribution CTR point to a factorial axis which showed the inertia percentage of the point that the axis absorbs

(2) The correlation COR point A to a factorial axis which was equal to the square of the cosine of the angle formed by the vector OA with the factorial axis, where $\mathrm{O}$ was the beginning of the axis.

The COR and CTR of the 18 factors/questions considered on the four principal axes (first four factorial axes) are presented in Table 7. In the creation of the first factorial axis the following factors contributed the most: employment prospects (E11_5 - CTR=227), the subject of studies (E11_6 - CTR=160), studies with a present and a future (E11_16 $\mathrm{CTR}=142)$ and mother's profession (E11_8 - CTR=103).

Table 7. COR (contribution) and CTR (correlation) coordinates of subjects

\section{Factor \#F1 COR CTR \#F2 COR CTR \#F3 COR CTR \#F4 COR CTR}

\begin{tabular}{lrrrrrrrrrrrr}
\hline E11_1 & -8 & 2 & 0 & -147 & 926 & 114 & 40 & 70 & 87 & -5 & 0 & 0 \\
E11_2 & -309 & 899 & 25 & -94 & 82 & 46 & 28 & 7 & 44 & 28 & 7 & 0 \\
E11_3 & 21 & 21 & 0 & -144 & 941 & 109 & 17 & 13 & 15 & -25 & 28 & 0 \\
E11_4 & -275 & 990 & 20 & -26 & 8 & 3 & -11 & 1 & 6 & 5 & 0 & 0 \\
E11_5 & 916 & 958 & 227 & 187 & 40 & 188 & 30 & 1 & 50 & -26 & 0 & 0 \\
E11_6 & 768 & 990 & 160 & 62 & 6 & 20 & -28 & 1 & 40 & 36 & 2 & 0 \\
E11_7 & -445 & 909 & 53 & 137 & 86 & 100 & -21 & 1 & 21 & -19 & 1 & 0 \\
E11_8 & -619 & 927 & 103 & 170 & 70 & 155 & 18 & 0 & 17 & 12 & 0 & 0 \\
E11_9 & -254 & 961 & 17 & 50 & 37 & 13 & 1 & 0 & 0 & -8 & 0 & 0 \\
E11_10 & 313 & 991 & 26 & -11 & 1 & 0 & 26 & 6 & 37 & -5 & 0 & 0 \\
E11_11 & -484 & 986 & 63 & 49 & 10 & 12 & -16 & 1 & 12 & -22 & 1 & 0 \\
E11_12 & -274 & 993 & 20 & -22 & 6 & 2 & 2 & 0 & 0 & -4 & 0 & 0 \\
E11_13 & 83 & 317 & 1 & -121 & 660 & 77 & -19 & 16 & 18 & -9 & 3 & 0 \\
E11_14 & -156 & 996 & 6 & -6 & 1 & 0 & 6 & 1 & 2 & -2 & 0 & 0 \\
E11_15 & 78 & 255 & 1 & -86 & 303 & 39 & -104 & 441 & 573 & 17 & 13 & 0 \\
E11_16 & 724 & 993 & 142 & 55 & 5 & 16 & -15 & 0 & 11 & 13 & 0 & 0 \\
E11_17 & 420 & 925 & 47 & -116 & 69 & 71 & 29 & 4 & 45 & -13 & 0 & 0 \\
E11_18 & -511 & 986 & 70 & 56 & 11 & 16 & 9 & 0 & 4 & 18 & 1 & 0 \\
\hline
\end{tabular}

When the 18 considered factors on the principal factorial axis are projected, the importance of each factor for the university department selection of the students (male and female) is clearly visible. This projection is pictured in Figure 1 (presented as output of the used software package MAD). Each of the 18 factors is depicted so that the more left the factor is shown, the less its importance is. 


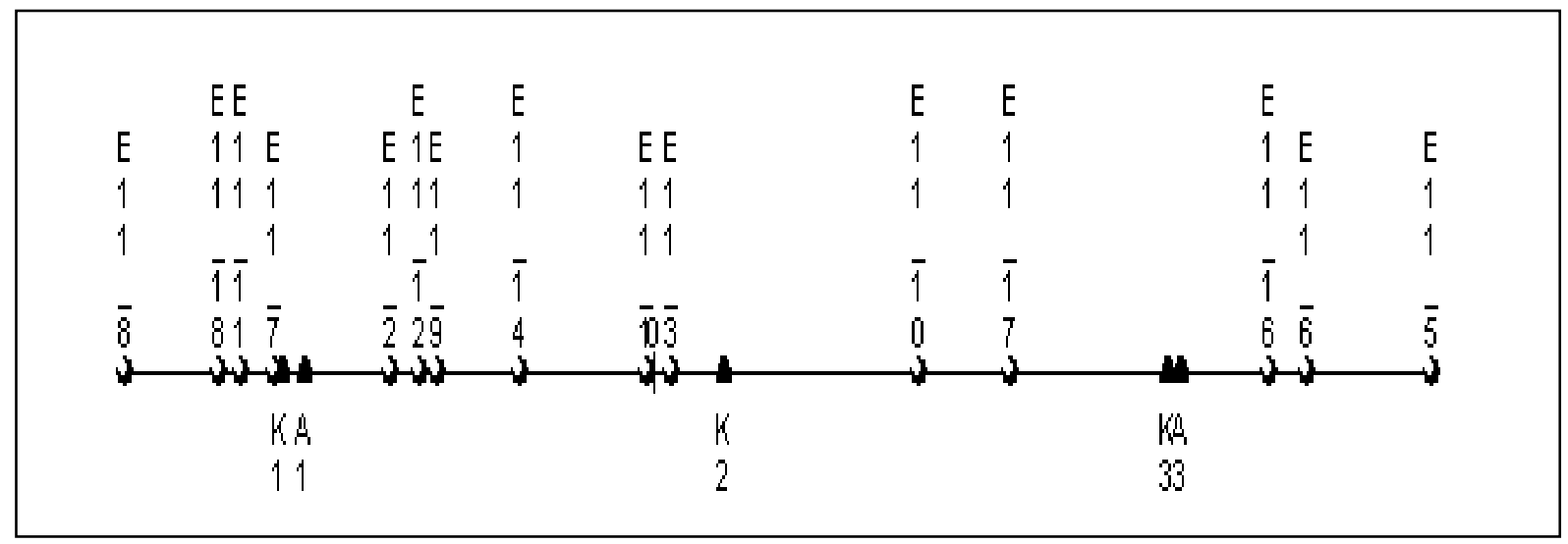

Figure 1. Projection on the first factorial axis $(94.59 \%)$

In the first factorial axis it is observed that male and female students are equally influenced by the same factors. In particular, the following factors did not influence them at all in their selections: mother's profession (E11_8), psychological repercussions on the family due to distance from family residence (E11_18), high school friends (E11_11), father's profession (E11_7), school (E11_2), family financial status (E11_12), distance from family residence (E11_9), while they were "quite" influenced by: independence from parents (E11_14), family (E11_1), social environment (E11_3).

In contrary, the factors that influenced them significantly were: the city where the department is situated (E11_10), the social recognition (E11_17), the studies with a present and a future (E11_16), the subject of studies (E11_6), as well as the employment prospects (E11_5).

\section{Conclusions and Further Research}

This paper focuses on estimating and understanding the impact of a number of selected factors, which influence the decision making of potential accounting and finance students in Greek higher education establishments. For this purpose, a questionnaire survey based on long experience with high school candidates to introductory exams for Greek universities was addressed to a large number of students.

The analysis carried out shows that the main factors affecting the selection of a university department are not so much connected to family and local environment, as the relevant parameters have found to be insignificant. It has been found out that this selection is mainly related to the prospects established by a degree from a particular department for the future career of the corresponding graduate, as well as to relevant social recognition. These findings imply that a major contribution to the knowledge of university introductory exam candidates would be to provide thorough information regarding the career and future prospects of having a degree from any given university department. Additionally, the location of the department has been found to play an important role, reflecting directly to the aim of minimizing the cost of living during the higher education studies.

More studies in the spirit of this one can further shed light to the important issue of career management at the very early stages of the life of an individual, during the years of 
preparation (mental and educational) for entering the university. Moreover, the examination of the effects of additional, different than the examined ones, would maybe reveal new statistically significant effects.

\section{References}

Albrecht, W.S., \& Sack, R.J. (2001). The perilous future of accounting education. The CPA Journal, 71(3) March, 16-23.

Ashworth, J. (1969). The pursuit of high quality recruits. The Journal of Accountancy, February, 53-58.

Auyeung, P., \& Sands, J. (1997). Factors influencing accounting students' career choice: a cross-cultural validation study. Journal of Accounting Education, 6(1), 13-23. http://dx.doi.org/10.1080/096392897331596

Bundy, P., \& Norris, D. (1992). What accounting students consider important in the job selection process. Journal of Applied Business Research, 8, 1-6.

Carpenter, C.G., \& Strawser, R.H. (1970). Job selection preferences of accounting students. Journal of Accountancy, June, 84-86.

Cohen, J., \& Hanno, D.M. (1993). An analysis of the underlying constructs affecting the choice of accounting as a major. Issues in Accounting Education, 8(2) Fall, 219-238.

Dynan, K.E., \& Rouse C.E. (1997). The under-representation of women in economics: a study of undergraduate students. Journal of Economic Education, 28(4) Fall, 350-368.

Evans, P.K. (1974). The decision to become a chartered accountant. CA Magazine, January 107(1), 54-58.

Felton, S., Buhr, N., \& Northey, M. (1994). Factors influencing the business student' s choice of a career in chartered accountancy. Issues in Accounting Education, 9(1) Spring, 131-141.

Gammie, E., Paver, B., Gammie, B., \& Duncan, F. (2003). Gender differences in accounting education: an undergraduate exploration. Journal of Accounting Education 12(2), 177-196. http://dx.doi.org/10.1080/0963928032000091765

Ginzberg, E. (1951). Occupational Choice. New York: Columbia University Press.

Gul, F.A., Andrew, B.H., Leong, S.C., \& Ismail, Z. (1989). Factors influencing choice of discipline of study: accountancy, engineering, law and medicine. Accounting and Finance, 29, 93-101. http://dx.doi.org/10.1111/j.1467-629X.1989.tb00105.x

Horowitz, K., \& Riley, T. (1990). How do accounting students see US. Accountancy, September, 75-77.

Jensen, E.J., \& Owen, A.L. (2000). Why are women such reluctant economists? Evidence from liberal arts colleges. American Economic Review, 90(2) May, 466-470. http://dx.doi.org/10.1257/aer.90.2.466 
Kamran, A., Kazi, F., \& Manzurul, A. (1997). An empirical study of factors affecting accounting students' career choice in New Zealand. Journal of Accounting Education, 6(4), 325-335. http://dx.doi.org/10.1080/096392897331398

Lebart, L., Morineau, A., \& Piron, M. (2002). Statistique Exploratoire Multidimensionelle. Paris: Dunod.

Lewis, P., \& Norris, K. (1997). Recent changes in economics enrolments. Economic Papers, 16(1) March, 1-13. http://dx.doi.org/10.1111/j.1759-3441.1997.tb00135.x

Lowe, D.R., \& Simons, K. (1997). Factors influencing choice of business majors-some additional evidence: a research note. Journal of Accounting Education, 6(1), 39-45. http://dx.doi.org/10.1080/096392897331613

Markus, H.R., \& Kitayama, S. (1991). Culture and the self: implication s for cognition, emotion, and motivation. Psychological Review, 98, 224-253. http://dx.doi.org/10.1037/0033-295X.98.2.224

Moschidis, O. (2002). Evaluation scales: Measurement similarities in table $0-1.15^{\text {th }}$ Pan-hellenic Statistics Conference. Ioannina.

Moschidis, O. (2003). Proposal for the codification of evaluation scales. $16^{\text {th }}$ Panhellenic Statistics Conference. Kavala

Moschidis, O. (2006). Proposal of comparative evaluation with the correspondence analysis, Journal SPOUDAI, Vol. 56, No. 3, pp.95-113.

Moschidis, O., Papadimitriou, G., \& Hatzipantelis, Th. (2003). Proposal for the 'balancing' of vertical variables in Multiple Factor analysis. $2^{\text {nd }}$ Data Analysis Conference. Komotini.

O' Connor, J.P., \& Kinnane, J.F. (1961). A factor analysis of work values. Journal of Counselling Psychology, 8, 263-267. http://dx.doi.org/10.1037/h0047440

Paolillo, J., \& Estes, R. (1982). An empirical analysis of career choice factors among accountants, attorneys, engineers, and physicians. The Accounting Review, 57(4), 785-793.

Saemann, G.P., \& Crooker, K.J. (1999). Students' perceptions of the profession and its effect on decisions to major in accounting. Journal of Accounting Education 17(1) Winter, 1-22. http://dx.doi.org/10.1016/S0748-5751(99)00007-X

Thielens, W., Jr. (1974). Why and when accountants choose their career. The Practical Accountant, March/April, 44-45.

Triandis, H.C., Brislin, R., \& Hui, C.H. (1988). Cross-cultural training across the individualism collectivism divide. International Journal of Intercultural Relations, 12, 269-289. http://dx.doi.org/10.1016/0147-1767(88)90019-3

Triandis, H.C., McCusker, C., \& Hui, C.H. (1990). Multimethod probes of individualism and collectivism. Journal of Personality and Social Psychology, 59, 1006-1020. http://dx.doi.org/10.1037/0022-3514.59.5.1006 


\section{Macrothink}

Worthington, A.P., \& Higgs, H. (2003). Factors explaining the choice of a finance major: the role of students' characteristics, personality and perceptions of the profession. Journal of Accounting Education, 12(1), 1-21. http://dx.doi.org/10.1080/0963928032000088831

Zardas, G., Moschidis, O.,Mavridis, I., \& Manitsaris, A. (2011) 'A methodology for evaluating web-based educational systems using statistical multidimensional analysis', International Journal of Learning Technology, Vol. 6, No. 4, 409-432. http://dx.doi.org/10.1504/IJLT.2011.044631 